\title{
Catalyzing Action on First Nations Respiratory Health Using Community-based Participatory Research: Integrated Knowledge Translation through Strategic Symposia
}

\author{
Tarun R. Katapally, Sylvia Abonyi, Jo-Ann Episkenew, Vivian R Ramsden, Chandima \\ Karunanayake, Shelley Kirychuk, Donna Rennie, James Dosman, Punam Pahwa
}

\begin{abstract}
Assess, Redress, Re-assess: Addressing Disparities in Respiratory Health Among First Nations is an ongoing community-based participatory research initiative involving two First Nations communities in Saskatchewan. The initiative's rationale is grounded in the ethos of transformative community-based participatory research and facilitated through integrated knowledge translation with the aim of building community capacity. The initiative's goal was to engage community members to actively participate in all research phases, from the development of the research questions to dissemination of results and evaluation of community-chosen interventions that evolved from the results. After baseline assessment of predictors and indicators of respiratory health, a program of integrated knowledge translation was adopted. As part of this program, a community-researcher collaboration was put in place that produced two knowledge translation symposia. The two symposia have brought together First Nations community members, interdisciplinary researchers, federal and provincial policy makers, and multiple Aboriginal organizational stakeholders. The symposia provided a pathway for knowledge synthesis and sharing to ultimately integrate knowledge into practice and enable First Nations' community capacity building in addressing and redressing critical respiratory health issues. This article delineates the processes involved in developing this model of integrated knowledge translation and highlights the continuing engagement with the participating communities supported by Knowledge Translation (KT) Symposia.
\end{abstract}

KEYWORDS integrated knowledge translation; community-based research; Indigenous health

Health inequities among Indigenous peoples (First Nations, Métis, and Inuit) in Canada cause significant disparities in determinants of health, especially rates of non-traditional use of tobacco and increased indoor air pollutants due to inadequate housing (Barsh, 1994; Health Canada, 2009; Statistics Canada, 2008). Disparities in determinants of health in turn lead to inequalities in health outcomes. For instance, poor housing conditions such as housing in need of major repairs (Statistics Canada, 2008); dampness and mould (Lawrence et al., 2001; Michel et al., 1996; Park et al., 2001; Rizzo et al., 1997); adverse indoor air quality due to overcrowding, and both active and passive smoking from the non-traditional use of tobacco (Crighton et al., 
2010), lead to tuberculosis (Brunekreef et al., 1989), severe respiratory infections (Sin et al., 2008), and other respiratory diseases (Clark et al., 2002; Dales et al., 1991; Kovesi et al., 2007).

These inequalities are unsustainable especially due to the faster growth of the Indigenous population in comparison with the rest of the Canadian population (Statistics Canada, 2014). Moreover, with geography primarily determining access to health care (Kirby et al., 2002; Romanow, 2002) and "place" being an important population health variable (Canadian Institute of Health Information, 2006), the respiratory health risks faced by Indigenous Peoples are further accentuated in rural Indigenous populations due to their geographic and economic isolation (Health Canada, 2009; Statistics Canada, 2008).

The aim of this essay is to extend a model of integrated knowledge translation within the context of community-based participatory research with Indigenous communities, by describing how the evidence generated by the main components of a community-based participatory research initiative was translated through two knowledge translation symposia.

\section{Community-Based Participatory Research Initiative}

'Assess, Redress, Re-assess: Addressing Disparities in Respiratory Health Among First Nations People' is a community-based participatory research initiative in two First Nation reserves in Saskatchewan. The initiative's rationale is rooted in the concept of participatory action research facilitated by integrated knowledge transfer to build community capacity. The design enables active participation of community members in all phases of research, from the development of research questions to the dissemination of results and the evaluation of interventions implemented based on the results.

Based on Health Canada's Population Health Framework of understanding the influence of individual and contextual factors on health outcomes (Health Canada, 1994; Pahwa et al., 2012; Pickett et al., 2008), this initiative aims to implement appropriate community-level (address) and policy-level (redress) interventions to tackle respiratory health inequalities and inequities. However, before developing interventions, the initiative was structured into two key phases: vision and relationships leading to problem identification and baseline assessment of respiratory health determinants and outcomes. The "Vision and Relationships" phase involved a two-year dialogue with participating communities, where four exposure-outcome dyads were identified by the communities as key factors driving respiratory health inequalities: i) the quality of housing and mould within the houses - asthma, especially in children; ii) smoking in general, and smoking in homes resulting in environmental tobacco smoke_chronic obstructive pulmonary disease; iii) overcrowding and infections_-bronchitis ; iv) body weight_obst sleep apnea (Pahwa et al., 2015). Table 1 is the Logic Model of the initiative, which enumerates the four phases of the study, including the assessment of the four exposure-outcome dyads. 
Table 1: Logic Model

\begin{tabular}{|c|c|c|c|c|}
\hline $\begin{array}{l}\text { Issue } \\
\text { (Identified } \\
\text { problems) }\end{array}$ & $\begin{array}{l}\text { Assess } \\
\text { (Baseline) }\end{array}$ & $\begin{array}{l}\text { Address } \\
\text { (Community- } \\
\text { level) }\end{array}$ & $\begin{array}{l}\text { Redress } \\
\text { (Policy-level) }\end{array}$ & $\begin{array}{l}\text { Reassess } \\
\text { (Outcome } \\
\text { measures) }\end{array}$ \\
\hline $\begin{array}{l}\text { Housing } \\
\text { Dampness, } \\
\text { mould, } \\
\text { endotoxin } \\
\text { Environmental } \\
\text { tobacco smoke } \\
\text { Wood/oil } \\
\text { heating }\end{array}$ & $\begin{array}{l}\text { Environmental } \\
\text { measures } \\
\text { Asthma in } \\
\text { children }\end{array}$ & $\begin{array}{l}\text { House keeping } \\
\text { Managing asthma } \\
\text { "Outdoor } \\
\text { living room" } \\
\text { (celebrating } \\
\text { smoke-free } \\
\text { homes) }\end{array}$ & \begin{tabular}{|l} 
Household \\
mould \\
remediation \\
Housing \\
policy
\end{tabular} & $\begin{array}{l}\text { Reduction in } \\
\text { wheezing among } \\
\text { children } \\
\text { Reduction in } \\
\text { smoking in houses } \\
\text { with children and } \\
\text { older adults }\end{array}$ \\
\hline $\begin{array}{l}\text { Smoking: non- } \\
\text { traditional use } \\
\text { of tobacco }\end{array}$ & $\begin{array}{l}\text { Symptoms } \\
\text { COPD } \\
\text { Lung function }\end{array}$ & $\begin{array}{l}\text { "Breath of Fresh } \\
\text { Air Campaign" } \\
\text { Management of } \\
\text { COPD }\end{array}$ & $\begin{array}{l}\text { Support for } \\
\text { culturally } \\
\text { appropriate } \\
\text { smoking } \\
\text { cessation }\end{array}$ & $\begin{array}{l}\text { Reduction in } \\
\text { smoking in } \\
\text { graduating } \\
\text { grade } 12 \\
\text { Improvement in } \\
\text { lung function }\end{array}$ \\
\hline $\begin{array}{l}\text { 3. Infections } \\
\text { Over crowding }\end{array}$ & Bronchitis & $\begin{array}{l}\text { Immunization } \\
\text { Flu vaccine } \\
\text { Prompt treatment }\end{array}$ & $\begin{array}{l}\text { Housing } \\
\text { policy } \\
\text { (crowding) }\end{array}$ & $\begin{array}{l}\text { Reduction in } \\
\text { flu cases and } \\
\text { respiratory } \\
\text { infections }\end{array}$ \\
\hline Body Weight & Sleep Apnea & $\begin{array}{l}\text { Identify cases } \\
\text { Community } \\
\text { sports } \\
\text { Combined } \\
\text { initiative } \\
\text { with diabetes } \\
\text { programs }\end{array}$ & $\begin{array}{l}\text { Access to } \\
\text { healthy/ } \\
\text { nutritive food } \\
\text { Equipment } \\
\text { for treating } \\
\text { sleep apnea }\end{array}$ & $\begin{array}{l}\text { All diagnosed } \\
\text { cases of sleep } \\
\text { apnea treated } \\
\text { Reduction in } \\
\text { average weight }\end{array}$ \\
\hline
\end{tabular}

Finally, an agreement was signed that addressed co-ownership of data between researchers and communities and respect for confidentiality and privacy. Thereafter, the baseline assessment (data collection and analysis) was completed in two stages in 2012 and 2013 with community members being trained to participate in data collection. The first stage was making people aware of the baseline survey, through door-to-door canvassing, and distributing brochures explaining the need and purpose of the study. The second stage consisted of inviting community members (both children and adults) to participate in questionnaires and undergo clinical assessments. Before conducting the various aspects of the study, a Certificate of Approval 
was obtained from the University of Saskatchewan's Bio-Medical Research Ethics Board. Moreover, before implementing the second stage of this phase, informed consent from all participants was obtained. The complete methodology of this community-based participatory research initiative has been published and describes in detail not only the development, but also the implementation of measures (Pahwa et al., 2015).

\section{Action: Community-Chosen and Policy-Level Interventions}

The data generated during the baseline assessment phase informed the community and policylevel interventions. The interventions are currently at various stages of development and implementation, and have been enumerated in Figures 2 and 3, the two figures that describe the activities of the knowledge translation symposia. To address the quality of housing at the community-level, an environmental study has been conducted during which 144 homes underwent environmental assessments in the two participating communities between January and April 2014. Environmental assessments included an interviewer-administered housing survey, floor dust collection, and temperature and relative humidity measures. Homes were visited between January and April 2014. Currently the data are being analyzed, and the results will inform a community-level intervention addressing housing conditions.

To address non-traditional use of tobacco in the communities, an evidence-informed and community-driven, community-level intervention called the Green Light Program was implemented with and in the communities. The Green Light Program identifies and celebrates smoke-free homes (Ramsden et al., 2013). As traditional use of tobacco in many First Nations communities is "sacred" and has cultural, medicinal, and spiritual implications, the focus of the Green Light Program is on non-traditional or misuse of tobacco.

Finally, to redress obstructive sleep apnea in First Nations at the policy-level, a complex policy and healthcare program analysis was conducted by interviewing key federal and provincial administrators and sleep specialists in Saskatoon. This analysis was conducted by taking into consideration the historical and jurisdictional complexity of healthcare provision to First Nations. Under the Canadian Constitution, healthcare is a provincial responsibility; however, Indigenous people with "Registered Indian" status are considered the responsibility of the federal system when it comes to extended health benefits (Government of Canada, 2014). The policy analysis generated evidence of bifurcated health care policy resulting in inequities in access to obstructive sleep apnea care. These three interventions are the key examples of the community-chosen intervention projects evolving from the larger initiative of our community-based participatory research project.

\section{Integrated Knowledge Translation}

The success of these ongoing interventions is dependent on the principles of integrated knowledge translation. According to the Canadian Institutes of Health Research, integrated knowledge translation involves the engagement of stakeholders or potential research knowledge users in the entire research process. By incorporating integrated knowledge translation, researchers and community members co-create the research questions which determine the 
methodology; that is, how and in what ways they will be involved in data collection, tool development, interpretation of results, and how best to share the results with the community and beyond. This collaborative and action-oriented approach is the essence of our research initiative (Canadian Institutes of Health Research, 2015).

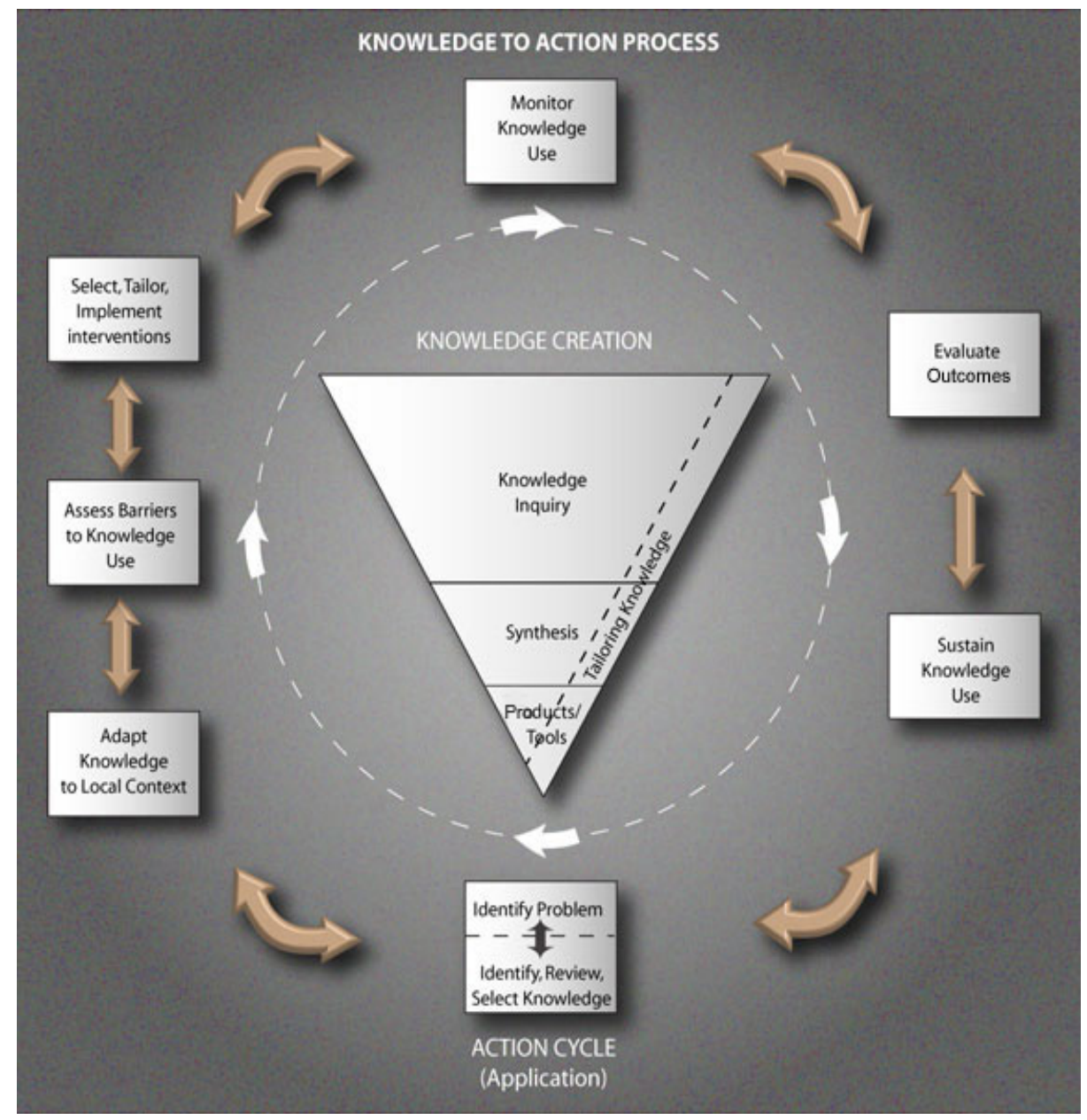

Figure 1: The Knowledge to Action Process

Adapted from CIHR (2013) Knowledge to Action Process

As enumerated in the background section, our initiative began with the development of strong relationships with the participating communities, which led to problem identification and co-creation of the research question(s). Thereafter, the communities have been involved in all phases of the initiative including data collection and the development and implementation of community-chosen and policy-level interventions. In moving from problem identification 
to implementation of the community-chosen interventions, and from evaluation of outcomes to knowledge translation with the communities, our approach closely mirrors the Canadian Institutes of Health Research's Knowledge to Action Process (Canadian Institutes of Health Research, 2015). However, the key element in this integrated knowledge translation model was the knowledge exchange between the researchers and the community members that was facilitated during two Annual Symposia.

\section{The Symposia}

The two symposia brought together community members, interdisciplinary researchers, federal and provincial policy makers (e.g., First Nations and Inuit Health, Indian and Northern Affairs Canada), and multiple Aboriginal organizational stakeholders (e.g., Federation of Saskatchewan Indian Nations, Northern Inter-Tribal Health Authority) to create a platform for knowledge sharing, synthesis and transfer. The symposia were structured to foster debate and discussion among the key stakeholders and to highlight important themes of inquiry, which in turn would provide direction to community-chosen (address) and policy-level (redress) interventions. In terms of building the stakeholder groups, there was a deliberate attempt to create groups that included First Nations housing and health (Aboriginal Affairs and North Development Canada, and First Nations and Inuit Health), provincial First Nations governance, community leaders, members, and Elders. One major challenge that needs to be highlighted here is the difficulty in crossing the structural silos between First Nations housing and health, which was evident in the lack of combined representation from Aboriginal Affairs and North Development Canada, and First Nations and Inuit Health.

\section{Symposium 1 (2013)}

The day began with researchers from the Universities of Saskatchewan and Regina, who are affiliated with the Canadian Centre for Health and Safety in Agriculture and the Indigenous Peoples' Health Research Centre, presenting important baseline results. These results were from interviewer-administered questionnaires (e.g., presence of mould, household smoking) and an objective assessment of respiratory health (e.g., presence of respiratory symptoms). These presentations were carried out in a Rotating Round Table format, in which a researcher was seated at each table and the attendees moved from table to table. Attendees were divided into small groups that included a spectrum of stakeholders.

Each group spent 15 minutes at a table with a researcher who highlighted particular results and facilitated discussion with the stakeholders on the significance of these results. This format allowed the stakeholders to talk directly with each other and with the researcher about specific results. The main research results presented were related to the housing conditions, which triggered the ensuing Round Table discussions around the relationship between respiratory symptoms and poor housing conditions. 
At each table, an independent observer captured the discussions in unstructured written notes, often called field notes. Inductive, thematic analysis of these field notes revealed several themes. The themes that evolved were asthma; non-traditional use of tobacco; housing; and, overcrowding. Asthma was perceived to be a common health issue and smoking indoors was believed to exacerbate asthma in children. The conversation then shifted to housing conditions, and air filters were identified as protection for asthma and related symptoms. Housing conditions dominated the conversation at all Round Table discussions. Overcrowding was acknowledged as a major factor that was associated with home damage, sickness and general domestic conflict.

The conversations also captured the challenges faced by the communities in addressing the poor housing conditions. One factor that was mentioned was the fear among community members in losing their housing if they reported the need for repairs. Community members also reported the challenges associated with low income and difficulty obtaining bank loans for house repairs. Despite these challenges, there was consensus among stakeholders that community-based participatory research had a role in advising and advocating with band councils and community members for making house repairs a priority. The stakeholders especially acknowledged the importance of scientific inquiry in informing and influencing policymakers through empirical evidence on social and health problems related to poor housing conditions.

Following the Round Table discussions, a series of presentations focused on possible community-based programs and policy interventions to address and redress the key issues from the baseline research results. Each intervention presentation included discussion time. The day concluded with a multi-stakeholder panel discussion to further highlight emergent concerns and to identify research and intervention priorities moving forward. The Saskatchewan research team met the following day to determine next steps for research and intervention.

This Symposium not only served as a pilot for future dialogue, but also provided essential directions to address and redress the link between housing conditions and respiratory health in two First Nations communities. A follow-up symposium was planned for the fall of 2014, in which the goal would be to translate knowledge on community-chosen interventions and results into action beyond poor housing conditions.

\section{Symposium 2 (2014)}

Similar to Symposium 1, Symposium 2 was a daylong event that brought together the key stakeholders and researchers. Based on the positive response to the Round Table discussions during Symposium 1, Symposium 2 consisted of Round Table discussions that extended the knowledge translation beyond housing conditions. Whereas the stakeholders moved from table to table in the first symposium, in the second symposium it was the researchers who moved around tables. This made transitions shorter and less chaotic. Two key interventions that were discussed were the policy-level obstructive sleep apnea intervention and the communitychosen intervention on non-traditional use of tobacco. The discussion on obstructive sleep apnea revealed the need to conduct a community-level intervention to raise awareness and to 
reduce obesity rates, as obstructive sleep apnea is closely related to obesity.

The Green Light Program was discussed at length, with community members being provided the breadth of the program across multiple communities in Saskatchewan. The community members responded positively to the fact that the Green Light Program's guiding values are respect for oneself and others; build trust and relationships; responsibility and accountability of individual and the community; freedom of the individual; kindness and compassion; patience; and humility and compassion (Ramsden et al, 2013).

Apart from the discussions regarding the ongoing interventions, Symposium 2 also included Round Table discussion on the role of communities in integrated knowledge translation and the role of Indigenous Knowledge in informing policy and practice. This approach was to reiterate to the communities and the key stakeholders that the ultimate goal of our research is to help build and sustain the community-chosen interventions in and with the community through building capacity.

\section{Next Steps and Future Directions}

Following the Logic Model (Table 1), the next phase in this initiative is to "reassess/evaluate" the outcomes of interest and the community-chosen interventions. In this process, a second round of data collection will be conducted in partnership with communities. Building on the previous symposia, the next Symposium will serve to facilitate the knowledge translation of the evaluation phase of the initiative. This approach to integrated knowledge translation aligns with the Canadian Institutes of Health Research's knowledge to action process, where the evaluation of outcomes ultimately leads to sustaining the use of the knowledge generated (Figure 1).

The ultimate goal of this research is to generate evidence to de-adopt ineffective policies and practices, and in turn, enable Indigenous communities and stakeholders to empower themselves. In doing this, it is imperative to develop evidence-based knowledge translation models to integrate Indigenous Knowledge and experience with empirical evidence. The model of integrated knowledge translation revolving around the strategic symposia facilitated not only the larger goal of community-based participatory research in a large multi-year initiative, but also provided a platform for replication and transferability in future endeavours. 


\begin{tabular}{|c|c|}
\hline 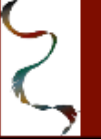 & $\begin{array}{l}\text { Symposium on First Nations Health \& Housing } \\
\text { November } 20,2013 \\
\text { Hilton Garden Inn, Saskatoon, SK }\end{array}$ \\
\hline \multicolumn{2}{|r|}{ Registration (9:30 - 10:00 AM) } \\
\hline $10: 00$ & Opening Prayer \\
\hline $10: 10$ & $\begin{array}{l}\text { Welcome, Structure of Day, Project Intro } \\
\text { Co-Chairs: Dr. Jo-Ann Episkenew and Dr. Sylvia Abonyi }\end{array}$ \\
\hline \multicolumn{2}{|r|}{ Knowledge About Housing \& Respiratory Health } \\
\hline $10: 20$ & Dialogue Session (15 minute speed meetings providing face-to-face dialogue opportunities) \\
\hline Table 1 & $\begin{array}{l}\text { Findings from the First Nations Lung Health Study at Montreal Lake Cree Nation \& Beardy's and } \\
\text { Okemasis First Nation } \\
\text { Dr. Punam Pahwa, University of Saskatchewan } \\
\text { Dr. James Dosman, University of Saskatchewan }\end{array}$ \\
\hline Table 2 & $\begin{array}{l}\text { Evaluating environments in First Nations housing } \\
\text { Dr. Shelley Kirychuk, University of Saskatchewan }\end{array}$ \\
\hline Table 3 & $\begin{array}{l}\text { Preliminary results of the Children's portion of the First Nations Lung Health Study } \\
\text { Dr. Donna Rennie, University of Saskatchewan }\end{array}$ \\
\hline Table 4 & $\begin{array}{l}\text { The Manitoba experience: Housing environments \& health amongst Manitoba First Nations } \\
\text { Peoples Dr. Linda Larcombe, University of Manitoba }\end{array}$ \\
\hline $11: 20$ & Facilitated Open Discussion - Co-Chairs: Jo-Ann and Sylvia \\
\hline \multicolumn{2}{|r|}{ LUNCH $(12: 00-1: 00)$} \\
\hline \multicolumn{2}{|r|}{ Addressing Housing \& Respiratory Health (Programs) } \\
\hline 1:00 & $\begin{array}{l}\text { What are the community people saying should be done? } \\
\text { Ms. Kathleen McMullin, University of Saskatchewan }\end{array}$ \\
\hline $1: 30$ & $\begin{array}{l}\text { What we are doing to repair houses in Montreal Lake Cree Nation? } \\
\text { Ms. Daisy Gamble, Housing Manager, Montreal Lake Cree Nation }\end{array}$ \\
\hline 2:00 & $\begin{array}{l}\text { Building on success - Celebrating smoke free homes } \\
\text { Dr. Vivian Ramsden, University of Saskatchewan, with Elder Betsy Henderson \& Jackie Crowe, } \\
\text { Greenlight Project team members }\end{array}$ \\
\hline \multicolumn{2}{|r|}{ REFRESHMENT BREAK (2:30 - 2:50) } \\
\hline \multicolumn{2}{|r|}{ Redressing Housing \& Respiratory Health (Policies) } \\
\hline $2: 50$ & Panel Introduction - Co-Chairs \\
\hline 3:00 & $\begin{array}{l}\text { Policy Panel Summary and Discussion } \\
\text { Mr. Jeremy Seeseequasis, Beardy's and Okemasis First Nation } \\
\text { Mr. Arnold Naytowhow, Montreal Lake Cree Nation } \\
\text { Dr. Greg Marchildon, University of Regina } \\
\text { Ms. Cassandra Opikokew, University of Regina } \\
\text { Dr. Tom Smith-Windsor. University of Saskatchewan }\end{array}$ \\
\hline $4: 00$ & Symposium Close \& Prayer \\
\hline & $\begin{array}{c}\text { DINNER \& ENTERTAINMENT (6:00 - 8:00 PM) } \\
\text { Station } 20 \text { West, } 1120 \text { - 20th Street West (hotel shuttle leaves the Hilton lobby at 5:30 pm) }\end{array}$ \\
\hline
\end{tabular}

Figure 2: Program of Symposium 1 (2013) 
66 Tarun R. Katapally, Sylvia Abonyi, Jo-Ann Episkenew, Vivian R Ramsden, Chandima Karunanayake, Shelley Kirychuk, Donna Rennie, James Dosman, Punam Pahwa

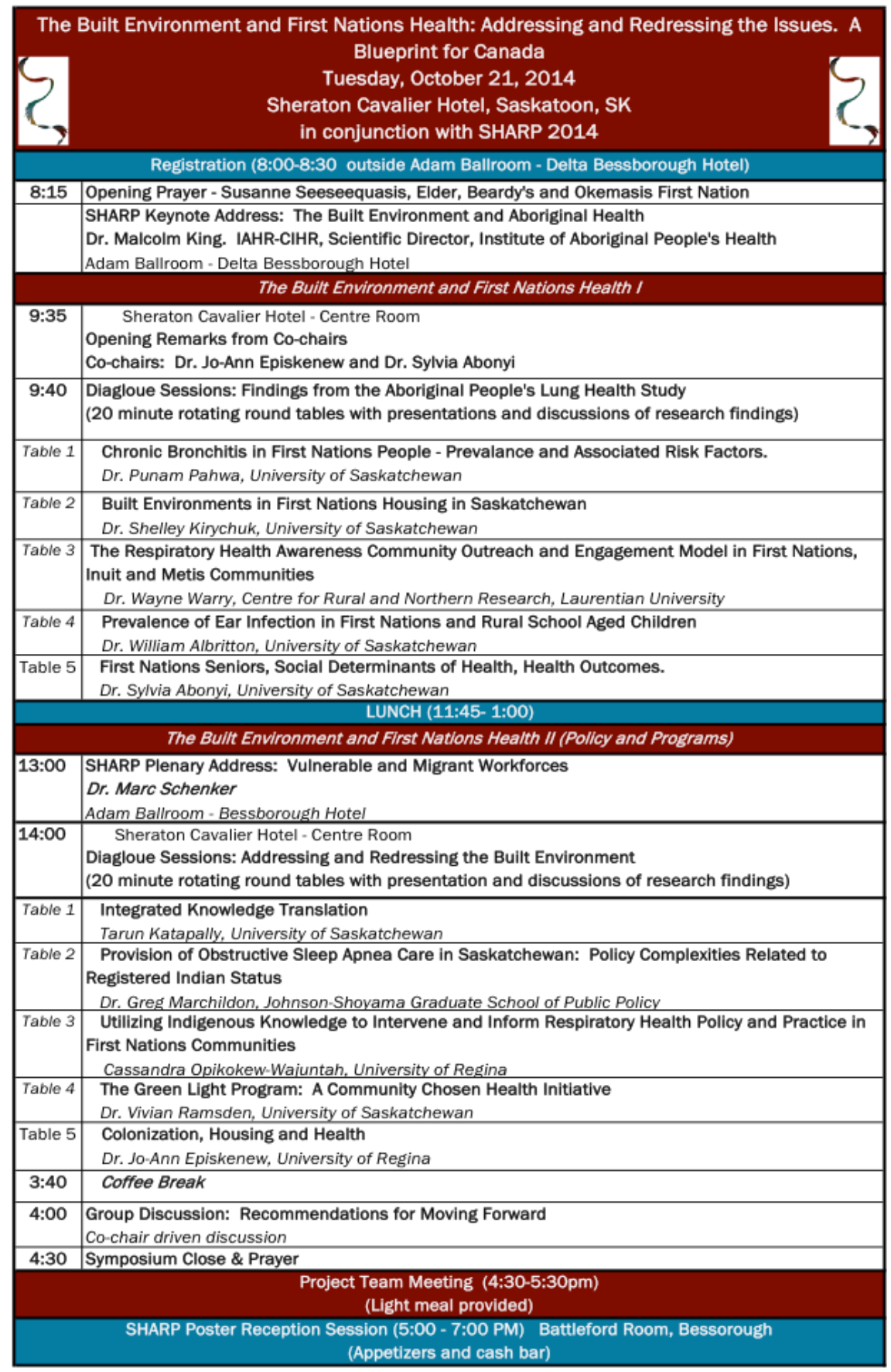

Figure 3: Symposium 2 (2014)

Engaged Scholar Journal: Community-Engaged Research, Teaching, and Learning 


\section{Acknowledgements}

We are grateful for the contributions from Elders, community leaders, School Boards, School Principals, teachers that facilitated the engagement necessary for the study, and all parents and children who donated their time to participate.

The First Nations Lung Health Project was funded by a grant from the Canadian Institutes of Health Research "Assess, Redress, Re-assess: Addressing Disparities in Respiratory Health among First Nations People,” CIHR MOP-246983-ABH-CCAA-11829.

The First Nations Lung Health Project Team consists of: James Dosman, MD (Designated Principal Investigator, University of Saskatchewan, Saskatoon, SK Canada); Dr. Punam Pahwa, PhD (Co-Principal Investigator, University of Saskatchewan, Saskatoon SK Canada); Jo-Ann Episkenew, PhD (Co-Principal Investigator, Aboriginal People's Health Research Centre, University of Regina, SK Canada), Sylvia Abonyi, PhD (Co-Principal Investigator, University of Saskatchewan, Saskatoon, SK Canada). Co-Investigators: Mark Fenton, MD; John Gordon, PhD; Bonnie Janzen, PhD; Chandima Karunanayake, PhD; Malcolm King, PhD; Shelly Kirychuk, PhD; Niels Koehncke, MD; Joshua Lawson, PhD; Greg Marchildon, PhD; Lesley McBain, PhD; Donna Rennie, PhD; Vivian R Ramsden, RN, PhD; Ambikaipakan Senthilselvan, PhD. Collaborators: Amy Zarzeczny, BA, LLM; Louise Hagel, MSc; Breanna Davis, MD; John Dosman, MD; Roland Dyck, MD; Thomas Smith-Windsor, MD; William Albritton, MD, PhD. External Advisor: Janet Smylie, MD, MPH; Project Manager: Kathleen McMullin, MEd; Community Partners: Jeremy Seeseequasis, BA; P. Jenny Gardipy, MPH; Laura McCallum, RN.

\section{About the Authors}

Sylvia Abonyi, an associate professor in the department of community health and epidemiology at the University of Saskatchewan (U of S). As a Canada Research Chair in Aboriginal Health, she is deeply committed to community driven action research and collaboratively investigates topics that include respiratory health, tuberculosis, type 2 diabetes, aging, food security, and frameworks and measures of community health.

James Dosman is considered the "Father of Agricultural Medicine" in Canada. In 2010 he was named Distinguished Research Chair, U of S, inducted as a Fellow of the Royal Society of Canada and named an Officer of the Order of Canada. As the co-principal applicant of this study, he is the driving force behind all research activities including the knowledge translation symposia. 
Jo-Ann Episkenew is a Métis woman originally from Manitoba but long-time resident of Saskatchewan. She is a professor of English at the First Nations University of Canada but has taken a leave of absence to serve as the director of the Indigenous Peoples' Health Research Centre. She is interested in studying the connection between story and healing and in applying literary analysis skills to her work with Indigenous youth.

Chandima Karunanayake is a professional research associate with the Canadian Centre for Health and Safety in Agriculture. Her research focuses on respiratory health in rural populations and her expertise is in utilizing complex statistical modeling in understanding distribution of diseases in populations.

Tarun Reddy Katapally (corresponding author) is an assistant professor at Johnson Shoyama Graduate School of Public Policy. His research includes policy-driven health care practice implications in First Nations and promotion of land-based physical activity in Indigenous youth. Email: Tarun.Katapally@uregina.ca

Shelley Kirychuk is an associate professor in the department of medicine at U of S. She is a co-investigator in this study and is working closely with the participating First Nations communities in addressing the impact of indoor pollutants on respiratory health.

Dr. Punam Pahwa is a professor in the department of community health and epidemiology at $\mathrm{U}$ of $\mathrm{S}$ and research faculty with Canadian Centre for Health and Safety in Agriculture. She brings statistical expertise and extensive research experience in respiratory health in rural Saskatchewan. Dr. Pahwa is a co-principal applicant of this study and along with Dr. Dosman is responsible for managing the overall project.

Vivian Ramsden is an associate professor and director of the research division in the department of academic family medicine at $U$ of $S$. She is a passionate advocate for communitybased participatory research and is currently leading a community-level intervention to address indoor smoking in the two participating First Nations communities.

Donna Rennie is an associate professor in the college of nursing at $\mathrm{U}$ of $\mathrm{S}$ and has extensive research experience in studying respiratory illnesses in rural populations. She is currently studying patterns and associations of asthma in children in the two participating First Nations communities. 


\section{References}

Allan, B., Smylie, J. (2015). First peoples, second class treatment. Retrieved September 23, 2015, from http://www.wellesleyinstitute.com/wp-content/uploads/2015/02/Report-First-PeoplesSecond-Class-Treatment-Feb-2015.pdf

Barsh, R. (1994). Canada's Aboriginal people: social integration or disintegration? The Canadian Journal of Native Studies, 14(1), 1-46.

Canadian Institute for Health Information. (2006). How healthy are rural Canadians? An assessment of their health status and health determinants. A component of the initiative "Canada's rural communities: Understanding rural health and its determinants." Canadian Institute for Health Information: Ottawa, ON, Canada. Retrieved September 23, 2015, from https://secure.cihi.ca/ free_products/rural_canadians_2006_report_e.pdf. 6, 2014.

Canadian Institutes of Health Research (2015). Knowledge translation. Retrieved September 29, 2015, from http://www.cihr-irsc.gc.ca/e/29418.html.

Clark, M., Riben, P., Nowgesic, E. (2002) The association of housing density, isolation and tuberculosis in Canadian First Nations communities. International Journal of Epidemiology, 31(5), 940-945.

Crighton, E., Wilson K., Senecal, S. (2010). The relationship between socio-economic and geographical factors and asthma among Canada's Aboriginal populations. International Journal of Circumpolar Health, 69(2), 138-150.

Dales, R.E., Burnett, R., Zwanenburg, H. (1991). Adverse health effects among adults exposed to home dampness and molds. American Review of Respiratory Diseases, 143(3), 505-509.

Government of Canada. (1985). Indian Act. Retrieved March 16, 2014, from http:/ /laws-lois.justice. gc.ca/eng/acts/i- 5/20130401/P1TT3xt3.html.

Health Canada (1994). Strategies for population health: Investing in the health of Canadians. Minister of Supply and Services Canada. Health Canada: Ottawa, ON, Canada. Retrieved September 04, 2014, from http://publications.gc.ca/collections/Collection/H88-3-30-2001/pdfs/other/ strat_e.pdf.

Health Canada (2009). A statistical profile on health of First Nations in Canada: determinants of health 1999-2003. Health Canada: Ottawa, ON, Canada. Retrieved February 05, 2015, from http:/ /www.hc-sc.gc.ca/fniah-spnia/alt_formats/fnihb-dgspni/pdf/pubs/aborigautoch/2009-stats-profil-eng.pdf.

Kirby, M., LeBreton, M. (2002). The health of Canadians: The Federal Role. Vol 6, Recommendations for reform. The Standing Senate Committee on Social Affairs, Science and Technology. Parliament of Canada: Ottawa, ON, Canada; 2002. Retrieved June 10, 2014, from http://www.parl.gc.ca/Content/SEN/Committee/372/soci/rep/repoct02vol6-e.pdf.

Kovesi, T., Gilbert, N., Stocco, C., Fugler, D., Dales, R., Guay, M., Miller, D. (2007). Indoor air quality and the risk of lower respiratory tract infections in young Canadian Inuit children. Canadian Medical Association Journal, 177(2), 155-160.

Lawrence, R., Martin, D. (2001). Moulds, moisture and microbial contamination of First Nations housing in British Columbia, Canada. International Journal of Circumpolar Health, 60(2), 150156. 
70 Tarun R. Katapally, Sylvia Abonyi, Jo-Ann Episkenew, Vivian R Ramsden, Chandima Karunanayake, Shelley Kirychuk, Donna Rennie, James Dosman, Punam Pahwa

Michel, O., Kips, J., Dutchateau, J., Vertongen, F., Robert, L., Collet, H, et al. (1996). Severity of asthma is related to endotoxin in house dust. American Journal of Respiratory and Critical Care Medicine, 154(6), 1641-1646.

Ministerial Advisory Committee on Rural Health (2002). Rural Health in Rural Hands: Strategic Directions for Rural, Remote, Northern and Aboriginal Communities. Health Canada: Ottawa, ON, Canada. Retrieved September 12, 2014, from http:// www.ruralontarioinstitute. ca $/$ file.aspx?id=29b5ba0b-c6ce-489f-bb07-2febfb576daa.

Pahwa, P., Karunanayake, C., Hagel, L., Janzen, B., Pickett, W., Rennie, D., . . Dosman, J.A. (2012). The Saskatchewan rural health study: an application of a population health framework to understand respiratory health outcomes. BMC Research Notes, 5, 400.

Pahwa, P., Abonyi, S., Karunanayake, C., Rennie, D.C., Janzen, B., Kirychuk, S., . . Dosman, J.A. (2015). A community-based participatory research methodology to address, redress, and reassess disparities in respiratory health among First Nations. BMC Res Notes, 8, 199.

Park, J.H., Gold, R., Spiegelman, D.L., Burge, H.A., Milton, D. (2001). House dust endotoxin and wheeze in the first year of life. American journal of respiratory and critical care medicine, 163(6), 322-328.

Pickett, W., Day, L., Brison, R.J., Marlenga, B.L., Pahwa, P., Koehncke, N., . . Dosman, J.A. (2008). The Saskatchewan Farm Injury Cohort: rationale and Methodology. Public Health Reports, 123(5), 567-575.

Ramsden, V.R., McKay, S., Bighead, S., Boucher, G., Bourassa, C., Butt, P., . . Turner, T. (2013). Participatory health research: celebrating smoke free homes. Canadian Family Physician, 59(9), 1014-1015.

Rizzo, M.C., Naspitz, C.K., Fernandez-Calda, E., LeeKey, R. F., Mimica, I., Sole, D. Endotoxin exposure and symptoms in asthmatic children. (1997). Pediatric Allergy and Immunology, 8,121126.

Romanow R. Building on values: The future of health care in Canada. Commission on the Future of Health Care in Canada. National Library of Canada: Ottawa, ON, Canada. Retrieved December 15, 2014, from http://www.cbc.ca/healthcare/final_report.pdf.

Sin, D.D., Wells, H., Svenson, L.W., Man, S.F.P. (2002) Asthma and COPD among Aboriginals in Alberta, Canada. Chest, 121, 1841-1846.

Statistics Canada. (2008). Aboriginal People in Canada in 2006: Innit, Métis and First Nations, 2006 Census. Statistics Canada: Ottawa, ON, Canada. Retrived Septermber 20, 2014, from http:/ /www12. statcan.ca/census-recensement/2006/as-sa/97-558/pdf/97-558-XIE2006001.pdf.

Statistics Canada. (2014). Aboriginal Peoples in Canada: First Nations People, Métis, and Inuit. National Household Survey 2011. Statistics Canada: Ottawa, ON, Canada. Retrieved June 10, 2014, from http://www12.statcan.gc.ca/nhs-enm/2011/as-sa/99-011-x/99- 011-x2011001-eng.pdf. 